\title{
Pengaruh Model Challenge Based Learning terhadap Kemampuan Berpikir Kritis Siswa SMA pada Materi Perubahan Iklim
}

\author{
Mar'atul Mukarromah ${ }^{1}$, Budijanto ${ }^{1}$, Dwiyono Hari Utomo ${ }^{1}$ \\ ${ }^{1}$ Pendidikan Geografi-Universitas Negeri Malang
}

\begin{tabular}{l}
\hline \hline INFO ARTIKEL \\
\hline Riwayat Artikel: \\
Diterima: $28-06-2019$ \\
Disetujui: $17-02-2020$ \\
\hline
\end{tabular}

\section{Kata kunci:}

challenge based learning; critical thinking skills; climate change; challenge based learning; kemampuan berpikir kritis; perubahan iklim

\author{
Alamat Korespondensi: \\ Mar'atul Mukarromah \\ Pendidikan Geografi \\ Universitas Negeri Malang \\ Jalan Semarang 5 Malang \\ E-mail: maratulm94@gmail.com
}

\begin{abstract}
ABSTRAK
Abstract: The ability of critical thinking is a high level of thinking skills that students must have in the $21^{\text {st }}$ century. The purpose of this research is to know the influence of challenge-based learning models to students' critical thinking ability. The research method used is a pseudo-experimentation with a quantitative approach. The subject of this study was high school students amounting to 60 people consisting of two homogeneous classes. Data collection techniques Using test essays are critical thinking abilities. The data analysis technique used is test T (T-Test). Statistical results of statistics show the value of the Sig. (2-tailed) is $0,003<0.05$, so the challenge-based learning model is significantly affected by students ' critical thinking skills.
\end{abstract}

\begin{abstract}
Abstrak: Kemampuan berpikir kritis merupakan kemampuan berpikir tingkat tinggi yang harus dimiliki oleh siswa pada abad ke 21. Tujuan penelitian ini adalah untuk mengetahui pengaruh model challenge based learning terhadap kemampuan berpikir kritis siswa. Metode penelitian yang digunakan yaitu eksperimen semu dengan pendekatan kuantitatif. Subjek penelitian ini adalah siswa SMA yang berjumlah 60 orang yang terdiri dari dua kelas yang bersifat homogen. Teknik pengumpulan data menggunakan tes esai kemampuan berpikir kritis. Teknik analisis data yang digunakan adalah uji $\mathrm{t}$ (t-test). Hasil uji statistik menunjukkan nilai Sig. (2-tailed) adalah $0,003<0,05$ sehingga model challenge based learning berpengaruh signifikan terhadap kemampuan berpikir kritis siswa.
\end{abstract}

Kemampuan berpikir kritis merupakan salah satu kemampuan abad ke 21 yang harus dimiliki oleh seseorang. Dalam kehidupan sehari-hari dimana siswa berinteraksi langsung dengan lingkungan sekitar tentu terjadi berbagai permasalahan yang membutuhkan penyelesaian yang tepat. Oleh karena itu, kemampuan berpikir kritis sangat penting untuk dimiliki oleh seorang siswa. Hal tersebut sesuai dengan pendapat (Hashemi, 2011) yang mengatakan bahwa melalui aktivitas berpikir kritis dapat meningkatkan keterampilan berpikir siswa sehingga dapat membantu dalam proses belajar siswa. Dalam aktivitas berpikir kritis siswa dituntut untuk menyelesaikan tugas dengan sebaik mungkin dengan cara menentukan informasi relevan yang dapat membantu dalam menyelesaikan tugas, mengembangkan berbagai pertanyaan yang mengarahkan untuk penyelesaian masalah, dan mempersempit topik yang disajikan, terlebih jika dihadapkan dengan permasalahan yang sering terjadi di lingkungan sekitar, seperti permasalahan perubahan iklim. Permasalahan yang terjadi tentu hanya dapat diselesaikan oleh seseorang yang memiliki kemampuan berpikir kritis. Oleh sebab itu, kemampuan berpikir kritis sangat penting untuk dikembangkan.

Materi atmosfer pada mata pelajaran Geografi merupakan salah satu materi yang memerlukan kemampuan berpikir kritis. Menurut (Sholihah, Utaya, \& Susilo, 2016) kemampuan berpikir kritis siswa dalam pembelajaran Geografi perlu dikembangkan untuk mengarahkan siswa memiliki kemampuan berpikir dalam memecahkan permasalahan lingkungan, memberikan solusi yang sesuai dan tepat dengan apa yang sedang terjadi. Salah satu topik pada materi atmosfer yang memerlukan kemampuan untuk menganalisis permasalahan yang terjadi di lingkungan sekitar adalah topik dampak perubahan iklim dan pengaruhnya terhadap kehidupan. Permasalahan iklim yang sedang marak terjadi belakangan ini mengharuskan siswa untuk memiliki kemampuan berpikir kritis. Pada materi tersebut banyak terjadi permasalahan lingkungan yang disebabkan oleh perubahan iklim yang membutuhkan pemecahan masalah yang baik. Hal tersebut menjadi kajian yang penting bagi para siswa. Karena keterlibatan siswa dalam penyelesaian masalah nyata dapat meningkatkan kemampuan berpikir kritis. Dengan memiliki kemampuan berpikir kritis siswa dapat memecahkan permasalahan. Melalui permasalahan nyata yang lekat dengan kehidupan akan menumbuhkan kemampuan berpikir kritis siswa (Ningsih, Hidayat, \& Kusairi, 2018). 
Upaya yang perlu dilakukan untuk meningkatkan kemampuan berpikir kritis siswa adalah dengan menerapkan model pembelajaran yang tepat, yaitu model yang melibatkan siswa aktif mencari informasi untuk memecahkan tantangan secara berkelompok melalui berbagai sudut pandang (Anwar, 2017). Salah satu model yang dapat mengonstruk pengetahuan siswa adalah model challenge based learning. Model challenge based learning dapat meningkatkan kemampuan berpikir kritis siswa. Model challenge based learning dimulai dari ide besar (big idea), pertanyaan penting (essential question), tantangan (the challenge), pertanyaan pemandu (guiding question), aktivitas pemandu (guiding activities), sumber pemandu (guiding resources), solusi (solution), penilaian (assesement), dan publikasi (publication) (Apple Education, 2011). Kemampuan berpikir kritis siswa akan dapat meningkat melalui sintaks dari model challenge based learning (Nawawi, 2016).

Tidak jauh berbeda dengan model pembelajaran lain, tentunya model challenge based learning juga memiliki kelebihan dan kelemahan. Adapun kelebihan model challenge based learning memiliki relevansi permasalahan yang diberikan dengan kehidupan nyata dan berfokus pada permasalahan yang diberikan (Baloian, Breuer, Hoeksema, \& Hoppe, 2006), proses pengambilan keputusan atau solusi, dan integrasi dengan teknologi (Johnson \& Adam, 2011). Untuk pelaksanaannya model challenge based learning juga dilaksanakan di luar kelas atau lingkungan sekitar siswa. Siswa secara langsung melakukan kegiatan observasi di lingkungan sekitar tempat tinggalnya untuk mengamati keadaan lingkungan sekitar dan menggali informasi yang dibutuhkan. Selama pengamatan siswa juga dituntut untuk berinteraksi langsung dengan masyarakat sehingga informasi yang didapatkan tidak hanya berasal dari buku atau sumber internet. Selama pengamatan siswa juga dituntut untuk berinteraksi langsung dengan masyarakat. Pemanfaatan lingkungan sebagai sarana belajar (Sularmi, Utomo, \& Ruja, 2018) tersebut memberi peluang siswa mendapat informasi secara langsung.

Model challenge based learning berpengaruh terhadap kemampuan berpikir kritis siswa. Hal tersebut dibuktikan oleh hasil penelitian yang dilakukan oleh (Saefi, Suwono, \& Susilo, 2017) menyatakan bahwa setelah dilakukan penelitian dengan model pembelajaran challenge based learning terjadi peningkatan kemampuan berpikir kritis mahasiswa secara signifikan. Oleh karena itu, berdasarkan permasalahan yang telah dipaparkan di atas, maka perlu dilakukan penelitian untuk mengetahui kemampuan berpikir kritis siswa dalam memecahkan masalah yang disebabkan oleh perubahan iklim.

\section{METODE}

Jenis penelitian ini merupakan jenis penelitian eksperimen semu (quasi experiment). Rancangan penelitian menggunakan pretest-posttest control group design. Kelas eksperimen diberi perlakuan dengan menerapkan model pembelajaran challenge based learning, sedangkan kelas kontrol tidak mendapat perlakuan dengan model (menggunakan pembelajaran konvensional berupa ceramah dan diskusi kelompok). Adapun penentuan subjek penelitian berdasarkan nilai ratarata ulangan siswa yang memiliki nilai yang hampir sama dibandingkan kelas lainnya.

Instrumen yang digunakan dalam penelitian ini menggunakan tes esai yang diberikan pada waktu pretest dan posttest. Tes yang diberikan berjumlah lima soal yang mencangkup kemampuan berpikir kritis. Sebelum diberikan pada kelas eksperimen dan kelas kontrol, instrumen tes diuji coba terlebih dahulu pada kelas uji coba. Setelah dilakukan uji coba dan tes dinyatakan layak kemudian diberikan pada kelas eksperimen dan kelas kontrol untuk pengambilan data kemampuan berpikir kritis. Tujuan dilakukan uji coba adalah untuk mengetahui apakah suatu instrumen telah memenuhi persyaratan (valid dan reliabel). Uji coba instrumen dilakukan pada siswa yang telah mempelajari materi atmosfer yaitu siswa kelas XI IPS 3. Uji instrumen dilakukan dengan menguji tingkat kesukaran, daya beda, validitas, dan reliabilitas tiap butir soal. Adapun analisis data yang digunakan yaitu uji prasyarat yang meliputi uji normalitas dan uji homogenitas serta uji hipotesis menggunakan uji t.

\section{HASIL}

Data hasil penelitian ini, meliputi (1) data pretest kemampuan berpikir kritis kelas eksperimen dan kelas kontrol, (2) data posttest kemampuan berpikir kritis kelas eksperimen dan kelas kontrol, dan (3) data gain score kemampuan berpikir kritis kelas eksperimen dan kelas kontrol. Untuk lebih jelas data rata-rata hasil kemampuan berpikir kritis siswa dapat dilihat pada tabel 1 .

Tabel 1. Distribusi Frekuensi Kemampuan Berpikir Kritis Kelas Eksperimen

\begin{tabular}{cccccc}
\hline & Pretest & & \multicolumn{3}{c}{ Posttest } \\
\hline Nilai & Frekuensi & Persentase & Nilai & Frekuensi & Persentase \\
\hline $70-75$ & 7 & $23 \%$ & $95-98$ & 3 & 10 \\
\hline $65-69$ & 6 & $20 \%$ & $91-94$ & 0 & 0 \\
\hline $60-64$ & 6 & $20 \%$ & $87-90$ & 8 & 27 \\
\hline $55-59$ & 5 & $17 \%$ & $83-86$ & 6 & 20 \\
\hline $50-54$ & 4 & $13 \%$ & $79-82$ & 6 & 20 \\
\hline $45-49$ & 2 & $7 \%$ & $75-78$ & 7 & 23 \\
\hline Jumlah & 30 & 100 & Jumlah & 30 & 100 \\
\hline
\end{tabular}


Tabel 1 menunjukkan bahwa nilai pretest kemampuan berpikir kritis siswa pada kelas eksperimen memperoleh nilai rata-rata (mean) sebesar 60,33. Nilai terendah berada pada interval 45-49 dengan frekuensi dua siswa atau 7\%. Selanjutnya rentang interval 50-54 diperoleh empat siswa dengan persentase 13\%, nilai interval 55-59 diperoleh lima siswa dengan persentase 17\%, nilai interval 60-64 diperoleh enam siswa dengan persentase 20\%, nilai interval 65-69 diperoleh enam siswa dengan persentase 20\%juga, dan nilai tertinggi berada pada interval 70-75 diperoleh 7 siswa dengan persentase $23 \%$.

Nilai rata-rata (mean) posttest kemampuan berpikir kritis siswa adalah 84. Nilai tertinggi berada pada rentang $95-98$ yang diperoleh tiga siswa dengan persentase $10 \%$, sedangkan nilai terendah berada pada rentang nilai $75-78$ yang diperoleh tujuh siswa dengan persentase 23\%. Adapun modus (nilai yang sering muncul) berada pada rentang $87-90$ yang diperoleh delapan siswa dengan persentase 27\%. Rentang nilai 83-86 diperoleh enam siswa dengan persentase $20 \%$, rentang nilai $79-$ 82 diperoleh enam siswa dengan persentase $20 \%$.

Tabel 2. Distribusi Frekuensi Kemampuan Berpikir Kritis Kelas Kontrol

\begin{tabular}{cccccc}
\hline & Pretest & & & Posttest & \\
\hline Nilai & Frekuensi & Persentase & Nilai & Frekuensi & Persentase \% \\
\hline $70-75$ & 7 & 23 & $85-86$ & 8 & 27 \\
\hline $65-69$ & 10 & 33 & $83-84$ & 0 & 0 \\
\hline $60-64$ & 6 & 20 & $81-82$ & 0 & 0 \\
\hline $55-59$ & 4 & 13 & $79-80$ & 10 & 33 \\
\hline $50-54$ & 1 & 4 & $77-78$ & 0 & 0 \\
\hline $45-49$ & 2 & 7 & $75-76$ & 12 & 40 \\
\hline Jumlah & 30 & 100 & Jumlah & 30 & 100 \\
\hline
\end{tabular}

Tabel 2 menunjukkan bahwa nilai rata-rata (mean) pretest kelas kontrol adalah 63. Nilai tertinggi berada pada interval 70 -75 diperoleh tujuh siswa dengan persentase $23 \%$, modus (nilai yang sering muncul) berada pada interval 65-69 diperoleh 10 siswa dengan persentase $33 \%$. Selanjutnya nilai interval 60-64 diperoleh enam siswa dengan persentase $20 \%$, nilai interval 55-59 diperoleh empat siswa dengan persentase 13\%, nilai interval 50-54 diperoleh satu siswa dengan persentase 4\%, dan nilai paling rendah diperoleh dua siswa dengan persentase $7 \%$.

Nilai rata-rata (mean) sebesar 79,33. Nilai tertinggi berada pada interval 85-86 yang diperoleh delapan siswa dengan persentase $27 \%$, nilai $79-80$ diperoleh 10 siswa dengan persentase $33 \%$, dan nilai terendah berada pada interval $75-76$ dengan persentase $40 \%$ diperoleh 12 siswa. Kemampuan berpikir kritis siswa diukur menggunakan soal yang diberikan ketika pretest dan posttest. Soal pretest dan posttest merupakan soal esai yang terdiri dari indikator berpikir kritis yaitu kemampuan merumuskan masalah, memberikan argumen, mengaitkan permasalahan, mengevaluasi berdasarkan fakta, membuat kesimpulan dan solusi. Berdasarkan tabel yang telah disajikan di atas maka dapat disimpulkan bahwa kemampuan berpikir kritis pada kelas eksperimen dan kelas kontrol sama-sama mengalami peningkatan nilai. Adapun peningkatan tersebut dapat dilihat pada tabel 3.

Tabel 3. Rata-rata Kemampuan Berpikir Kritis

\begin{tabular}{llll}
\hline Kelas & Pretest & Posttest & Gain Score \\
\hline Eksperimen & 60,33 & 84 & 23,33 \\
Kontrol & 63 & 79,33 & 16,17 \\
\hline
\end{tabular}

Berdasarkan tabel 3 dapat dilihat bahwa kemampuan berpikir kritis siswa ketika pretest pada kelas eksperimen memperoleh nilai rata-rata (mean) sebesar 60,33. Hasil posttest kemampuan berpikir kritis pada kelas eksperimen memperoleh nilai rata-rata (mean) sebesar 84. Penggunaan model challenge based learning pada kelas eksperimen dapat dikatakan berhasil dengan gain score sebesar 23,33. Sedangkan pada kelas kontrol yang menggunakan model pembelajaran ceramah dan diskusi juga mengalami peningkatan dari nilai pretest sebesar 63 mengalami peningkatan pada posttest sebesar 79,33 dengan gain score 16,17. Peningkatan nilai rata-rata pada kelas eksperimen mengalami peningkatan yang lebih tinggi jika dibandingkan dengan peningkatan pada kelas kontrol. Hal tersebut membuktikan bahwa penggunaan model challenge based learning dapat membuat peningkatan nilai siswa menjadi lebih tinggi.

\section{PEMBAHASAN}

Berdasarkan hasil penelitian menunjukkan bahwa model Challenge Based Learning berpengaruh terhadap kemampuan berpikir kritis siswa pada materi Perubahan Iklim siswa kelas X IPS SMA. Hal tersebut membuktikan bahwa nilai yang diperoleh kelas eksperimen yang menggunakan model challenge based learning lebih baik dibandingkan kelas kontrol yang menggunakan pembelajaran ceramah dan diskusi. Disamping itu, hasil uji homogenitas yang menggunakan analisis Independent Sample Test pada taraf signifikansi 95\% diperoleh nilai 0,229>0,05 yang berarti kedua varian homogen. Selanjutnya, hasil uji ttes juga menunjukkan bahwa pembelajaran yang menggunakan model challenge based learning berpengaruh terhadap kemampuan berpikir kritis siswa dengan signifikansi $0,003<0,05$. 
Proses pembelajaran dengan menggunakan model challenge based learning pada kelas eksperimen mengalami peningkatan yang lebih tinggi jika dibandingkan dengan kelas kontrol. Model challenge based learning merupakan model pembelajaran kooperatif yang tidak hanya melibatkan siswa, tetapi juga melibatkan guru untuk bersama-sama aktif dalam mencari solusi terhadap permasalahan yang dihadapi di lingkungan sekitar siswa. Langkah-langkah model challenge based learning terdiri dari beberapa tahapan sebagai berikut: Tahap I dimulai dengan menentukan ide besar (Big Idea) yang merupakan permasalahan yang bersifat global yang dapat diselesaikan dengan berbagai cara yang menarik dan memiliki manfaat bagi siswa dan masyarakat, misalnya keberlanjutan energi, perubahan iklim, dan kesehatan masyarakat (Apple Education, 2011). Adapun ide besar yang diangkat dalam penelitian ini adalah perubahan iklim setelah guru memberikan ide besar, langkah selanjutnya adalah siswa menentukan pertanyaan penting. Inti dari kegiatan tersebut adalah untuk mendapatkan tantangan (the challenge) berupa permasalahan perubahan iklim yang terjadi di sekitar tempat tinggal siswa.

Setelah siswa selesai mengidentifikasi tantangan, langkah selanjutnya adalah siswa diarahkan untuk menyusun pertanyaan pemandu. Pertanyaan pemandu merupakan bagian dari pertanyaan penting yang dikembangkan untuk mendapatkan solusi dari tantangan. Setelah siswa selesai menyusun pertanyaan pemandu, langkah selanjutnya adalah menentukan aktivitas pemandu seperti observasi dan wawancara pada masyarakat sekitar. Untuk mendukung semua kegiatan tersebut, maka siswa tentu perlu referensi atau pedoman berupa sumber pemandu (Johnson, et al 2009) yang biasa didapatkan di media, seperti situs web, Youtube, Instagram, dan lainnya. Pertanyaan pemandu, kegiatan pemandu, dan sumber pemandu berfungsi untuk mengarahkan siswa untuk menentukan apa saja yang diperlukan untuk memecahkan permasalahan dan langkah kerja seperti apa yang harus dilakukan. Tahap selanjutnya adalah mengidentifikasi solusi untuk memecahkan masalah yang telah ditetapkan sebagai tantangan dan langkah terakhir adalah penilaian dan publikasi (assesment and publication). Proses pembelajaran yang dimulai dari ide besar sampai publikasi didokumentasikan oleh siswa sebagai bahan laporan dalam bentuk video. Laporan yang sudah dibuat dalam bentuk video dipresentasikan di depan kelas untuk dinilai, setelah itu video yang sudah direvisi dipublikasikan di media sosial.

Model challenge based learning berpengaruh terhadap peningkatan kemampuan berpikir kritis siswa. Challenge based learning merupakan pengembangan dari model Problem Based Learning. Oleh sebab itu, antara model challenge based learning dan problem based learning memiliki karakteristik yang hampir sama, yaitu penekanan pada permasalahan kontekstual. (Arends, 2012) mengemukakan bahwa proses pembelajaran yang menekankan pada pengambilan keputusan pemecahan masalah didasarkan atas informasi yang dapat meningkatkan kemampuan berpikir kritis. Hal tersebut disebabkan karena masalah memberikan peluang untuk meningkatkan motivasi (Taufik, 2010) dalam diri siswa. Pada waktu kegiatan diskusi berlangsung siswa dituntut untuk memahami materi secara mendalam mengenai permasalahan yang dipresentasikan. Hal tersebut dapat membuat siswa merasa terdorong untuk mencari informasi yang lebih banyak. Siswa dari kelompok lain mengajukan pertanyaan maupun kritik dan saran yang disertai dengan argumentasi. Kritik dan saran yang diberikan siswa lain berakhir pada kesimpulan yang dapat diterima.

Perbedaan kemampuan berpikir kritis antara kelas eksperimen dan kelas kontrol terletak pada perlakuan yang diberikan. Kelas eksperimen diberi perlakuan menggunakan model challenge based learning, yang merupakan model yang melatih siswa untuk menyelesaikan tantangan tentang perubahan iklim yang terjadi di lingkungan sekitar. Siswa didorong untuk menemukan sendiri masalah yang terjadi di sekitar. Hal tersebut sesuai dengan yang diungkapkan oleh (Uno \& Mohammad, 2013) "proses belajar akan berjalan dengan baik dan kreatif jika guru memberikan kesempatan kepada siswa untuk menemukan sendiri masalah yang dihadapi, sedangkan kelas kontrol yang menggunakan pembelajaran konvensional berupa ceramah dan diskusi. Hal itulah yang menyebabkan kelas eksperimen memperoleh nilai yang lebih tinggi dibandingkan kelas kontrol.

Sintaks model challenge based learning yang meningkatkan kemampuan berpikir kritis siswa adalah sintaks menyusun pertanyaan pemandu (guiding question), kegiatan pemandu (guiding activities), dan sumber pemandu (guiding resources), dimana sintaks tersebut membiasakan siswa untuk memilih strategi yang cocok untuk menyelesaikan tantangan. Sintaks pertanyaan pemandu melatih siswa untuk mengidentifikasi permasalahan yang sedang terjadi. Hal tersebut sesuai dengan pernyataan (Wismath, Orr, Zhong, Wismath, \& Program, 2014) bahwa membiasakan siswa untuk menyusun pertanyaan dalam mengidentifikasi masalah dapat membantu mengembangkan aspek dalam kemampuan memecahkan masalah.

Model pembelajaran challenge based learning dapat mendorong siswa untuk merancang, meneliti, dan mendiagnosis suatu permasalahan. Pengetahuan yang diperoleh di sekolah jika diterapkan pada kehidupan nyata untuk memecahkan permasalahan akan dapat meningkatkan kemampuan siswa dalam menyelesaikan permasalahan. Proses pembelajaran yang menekankan pada pengambilan keputusan pemecahan masalah didasarkan pada informasi yang dapat meningkatkan kemampuan berpikir kritis siswa.

Kegiatan diskusi dan presentasi juga dapat meningkatkan kemampuan berpikir kritis siswa karena dalam proses tersebut siswa dituntut untuk memahami materi yang disampaikan secara lebih mendalam. Ketika kegiatan diskusi sedang berlangsung terjadi timbal balik antara siswa dengan siswa lainnya. Siswa yang lain akan menanggapi dan memberikan pendapat serta saran yang disertai argumentasi berdasarkan pertanyaan yang diajukan, sehingga akan mendorong siswa untuk melakukan evaluasi (Watson, 2012). Beberapa pendapat dan penelitian juga menunjukkan bahwa kegiatan diskusi yang disertai dengan penyampaian argumentasi dapat meningkatkan kemampuan berpikir kritis (Arends, 2012). 
Hal tersebut juga mendukung teori belajar konstruktivisme yang mendorong keterlibatan siswa secara langsung untuk mengembangkan sendiri pengetahuannya. Proses pembelajaran yang berlangsung pada penelitian ini membuat siswa mampu untuk mengonstruksi pengetahuan dengan permasalahan perubahan iklim yang terjadi di lingkungan sekitar. Senada dengan hal tersebut (Hayati, Utaya, Astina, 2016) menyatakan bahwa pembelajaran Geografi mengintegrasi kemampuan berpikir kritis melalui semua materi Geografi dengan pemecahan masalah lingkungan yang terjadi di lingkungan sekitar siswa sehingga dapat meningkatkan pengetahuan siswa terhadap materi. Masalah dalam konteks nyata dapat memberikan pengaruh pada peningkatan kemampuan berpikir kritis (Agustina, 2012) dimana pemikiran tersebut menunjang siswa bertambah kritis mengenali suatu fenomena (Nurrohmi, Utaya, \& Utomo, 2017). Berdasarkan teori dan temuan pada penelitian sebelumnya jika dikaitkan dengan penelitian ini hasilnya sangat relevan. Hasil penelitian ini diperkuat oleh penelitian sebelumnya yang menyebutkan bahwa model challenge based learning berpengaruh terhadap kemampuan berpikir kritis siswa.

\section{SIMPULAN}

Berdasarkan hasil penelitian maka dapat disimpulkan bahwa model challenge based learning berpengaruh terhadap kemampuan berpikir kritis siswa pada materi Atmosfer topik Perubahan Iklim dan Dampaknya terhadap Kehidupan. Nilai ratarata kemampuan berpikir kritis kelas eksperimen yang diberi perlakuan menggunakan model challenge based learning lebih tinggi dibandingkan kelas kontrol yang menggunakan model pembelajaran konvensional (ceramah dan diskusi).

Saran bagi guru Geografi yang menerapkan model challenge based learning hendaknya memilih ide besar dan materi yang sesuai dengan model pembelajaran ini. Bagi peneliti selanjutnya yang ingin menggunakan model challenge based learning disarankan agar lebih teliti dan menyiapkan perencanaan yang baik agar memperoleh hasil yang maksimal. Ada baiknya juga jika model challenge based learning ini dilaksanakan dengan blended learning agar kegiatan siswa dapat terus dipantau. Pemilihan materi yang sesuai dengan karakteristik model sangat memengaruhi peningkatan kemampuan berpikir kritis siswa.

\section{DAFTAR RUJUKAN}

Agustina, S. (2012). Pengaruh Model Pembelajaran Berdasarkan Masalah terhadap Kemampuan Berpikir Kritis dan Kreatif Mahasiswa Universitas Kanjuruhan Malang pada Matakuliah Hidrologi. Tesis tidak diterbitkan. Universitas Negeri Malang, Malang.

Anwar, B. M. H. A. (2017). Pengaruh Collaborative Learning dengan Teknik Jumping Task terhadap Keterampilan Berpikir Kritis dan Hasil Belajar Siswa. Jurnal Pembelajaran Sains, 1(2), 15-25.

Arends, R. I. (2012). Learning to Teach $9^{\text {th }}$ Edition. New York: McGraw-Hill.

Baloian, N., Breuer, H., Hoeksema, K., \& Hoppe, U. (2006). Implementing the Challenge Based Learning in Classroom Scenarios.

Hashemi, S. A. (2011). The Use Of Critical Thinking In Social Science Textbooks of High School: A Field Study of Fars Province in Iran. International Journal, 4(1).

Hayati, W. I., Utaya, S., \& Astina, I. (2016). Efektivitas Student Worksheet Berbasis Project Based Learning Dalam Menumbuhkan Kemampuan Berpikir Kritis Siswa pada Mata Pelajaran Geografi. Jurnal Pendidikan: Teori, Penelitian, dan Pengembangan, 1(3), 468-474.

Johnson., \& Adam. (2011). Challenge Based Learning: The Report from the Implementation Project.

Johnson, et al. (2009). Challenge-Based Learning An Approach for Our Time. Austin, Texas: New Media Consortium.

Nawawi, S. (2016). Potensi Model Pembelajaran Challenge Based Learning Dalam Memberdayakan Kemampuan Berpikir Kritis. Seminar Pendidikan Nasional, 1(1), 153-164.

Ningsih, P. R., Hidayat, A., \& Kusairi, S. (2018). Penerapan Problem Based Learning untuk Meningkatkan Kemampuan Berpikir Kritis dan Hasil Belajar Siswa Kelas III. Jurnal Pendidikan: Teori, Penelitian, dan Pengembangan, 3(12), 15871593.

Nurrohmi, Y., Utaya, S., \& Utomo, D. H. (2017). Pengaruh Model Pembelajaran Discovery Learning terhadap Kemampuan Berpikir Kritis Mahasiswa. Jurnal Pendidikan: Teori, Penelitian, dan Pengembangan, 2(10), 1308-1314.

Saefi, M., Suwono, H., \& Susilo, H. (2017). Studi Komparatif Tiga Strategi Berpikir Kritis Mahasiswa Biologi. Jurnal Pendidikan: Teori, Penelitian, dan Pengembangan, 2(5), 637-645.

Sholihah, M., Utaya, S., \& Susilo, S. (2016). Pengaruh Model Experiential Learning terhadap Kemampuan Berpikir Siswa SMA. Jurnal Pendidikan: Teori, Penelitian, dan Pengembangan, 1(11), 2096-2100.

Sularmi., Utomo, D. H., \& Ruja, I. N. (2018). Pengaruh Project-Based Learning terhadap Kemampuan Berpikir Kritis. Jurnal Pendidikan: Teori, Penelitian, dan Pengembangan, 3(4), 475-479.

Taufik, A. (2010). Inovasi Pendidikan Melalui Problem Based Learning. Jakarta: Kencana.

Uno, H. B., \& Mohammad, N. (2013). Belajar dengan Pendekatan PAILKEM. Jakarta: Remaja Rosdakarya.

Watson, G. \& G. E. (2012). Watson - Glaser Critical Thinking Appraisal Usher Guide and Tecnical Manual-. UK: Pearson Education Ltd.

Wismath, S., Orr, D., Zhong, M., Wismath, S., \& Program, L. E. (2014). Student Perception of Problem Solving Skills Authors' Contact Information Key Words : Teaching and Learning Journal, 7(3), 1-17. 